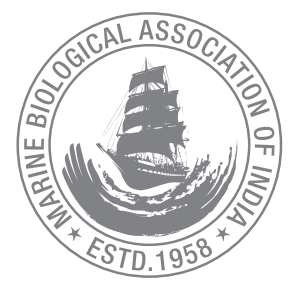

\title{
Range extension of striped triggerfish, Xanthichthys lineopunctatus (Hollard, 1854) (Tetradontiformis: Balistidae) in the eastern Indian Ocean
}

\author{
P. R. Behera*, Subhadeep Ghosh, K. Sreeramulu', K. K. Joshi' and M. A. Jishnudev \\ Visakhapatnam Regional Centre of ICAR-Central Marine Fisheries Research Institute,Visakhapatnam-530 003, India. \\ 'Department of Zoology, Andhra University, Visakhapatnam, India. \\ ${ }^{2}$ ICAR-Central Marine Fisheries Research Institute, Kochi, Kerala-682018. \\ ${ }^{*}$ Correspondence e-mail: beherapralaya213@gmail.com
}

Received: 10 July 2018 Accepted: 20 July 2018 Published: 30 July 2018

Short Communication

\begin{abstract}
A single specimen of Xanthichthys lineopunctatus (187 mm SL and weight $212 \mathrm{gm}$ ) was obtained from trawl net operated at depth range of 40-50 m off Visakhapatnam and landed at Visakhapatnam Fisheries Harbour on $20^{\text {th }}$ July 2016. It is reported for the first time from the east coast of India, Bay of Bengal. Earlier it was recorded from the south west coast of India, Arabian Sea and from the Indo-West Pacific. This report of Xanthichthys lineopunctatus in the Bay of Bengal extends its geographic distribution within the Indian Ocean.
\end{abstract}

Keywords: Visakhapatnam, range extension, Bay of Bengal, stripped triggerfish.

\section{Introduction}

Triggerfishes belonging to family Balistidae inhabit shallow waters, essentially on coral reefs, generally from just beneath the sea surface to $100 \mathrm{~m}$ depth. Fourty two species under twelve genera have been recorded from the world oceans (Froese and Pauly, 2016; Eschmeyer and Fong, 2016), fifteen species in twelve genera from Indian waters (Froese and Pauly, 2016). Fishes of the genus Xanthichthys are characterized by having cheek with three to six conspicuous grooves, no enlarged bony plates behind gill opening, and third dorsal spine minute not reaching out above dorsal edge of body. There are six species recognized within the genus Xanthichthys from world oceans $(X$. ringens, $X$. lineopunctatus, $X$. auromarginatus, $X$. mento, $X$. caeruleolineatus and $X$. greenel) (Randall et al.,1978). $X$. lineopunctatus is distributed in the tropical Indo-west Pacific from the east coast of Africa eastwards to North West Australia and north to the Ryukyu Islands. Nair et al. (2013) reported the species from the southwest coast of India. We here in report the species for the first time from the east coast of India.

\section{Material and methods}

A single specimen (187 mm SL and weight $212 \mathrm{gm}$ ) was obtained on $20^{\text {th }}$ July, 2016 in trawlnet operated at depth range of 40-50 
$\mathrm{m}$ off Visakhapatnam and landed at Visakhapatnam Fisheries Harbour (Fig.1). Randall et al. (1978) was followed for counts and measurements. Detailed measurements to the closest 0.1 $\mathrm{mm}$ was taken using digital caliper. First the identified specimen was preserved in $10 \%$ formaldehyde and later stored in $70 \%$ ethanol after complete washing.

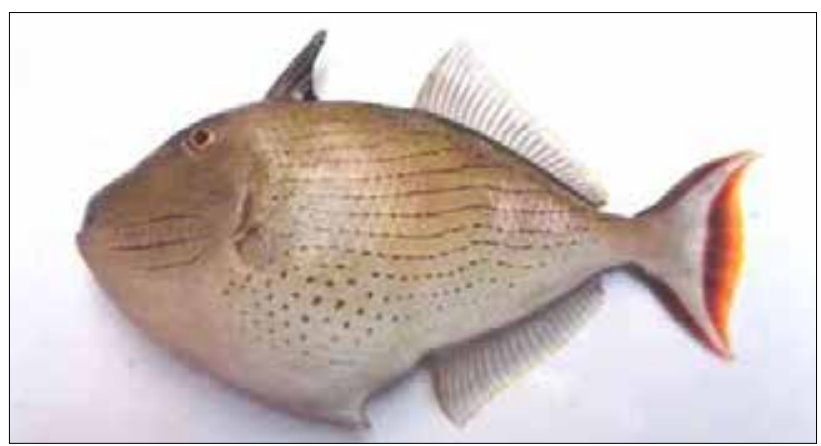

Fig. 1. Xanthichthys lineopunctatus landed at Visakhapatnam Fishing Harbor

\section{Results and discussion}

\section{Systematic position}

Order : Tetraodontiformes Berg, 1940

Family : Balistidae Risso, 1810

Genus : Xanthichthys Kaup, 1856

Species : Xanthichthys lineopunctatus (Hollard, 1854)

\section{Description}

Dorsal-fin rays III+28; anal-fin rays 25; pectoral-fin rays 13 . Nostrils small, placed just in front of eye (Fig.2a). A deep groove present on head in front of eye. Body scales rhomboidal and non-overlapping (Fig.2b). Scales on cheek rectangular in shape (Fig.2c). Scales on side of posterior portion of body with some tubercles forming longitudinal ridges (Fig.2d). Cheek with three diagonal dark brown grooves (a shorter narrower groove above and one below the main three) reaching out from behind and underneath the corner of the mouth almost to the gill opening. Longitudinal dark brown lines run on the dorsal part of body. No enlarged bony scales behind gill opening. Eight whitish teeth on each jaw which are sharply incisiform with tapering notched ends (Fig.2).

Body oval and compressed laterally. Head moderately long (HL 2.87 times $\mathrm{SL}$ ) and snout blunt. Eyes moderate and its diameter 4.51 times head length. Mouth small, supra-terminal. Two dorsal fins present, first dorsal fin with three obvious spines, second spine more than $1 / 2$ length of first spine. Soft dorsal fin and anal fin slightly concave on margin. Soft dorsal, anal, and pectoral fin rays branched. Pectoral fins short and broad whereas pelvic fin is rudimentary and represented by series of four pairs of enlarged scales encasing posterior end of pelvis.
Gill opening short, slightly oblique slit in front of pectoral-fin base. Scales on side of posterior half of body with some enlarged tubercles in the median line, forming feeble longitudinal ridges. Caudal fin lunate.

Body yellowish brown on dorsal side and lighter on the ventral side. There are a couple of incomplete reddish brown lines on dorsal side of body running longitudinally from just above the dorsal end of gill opening to below origin of soft dorsal fin. Many dark brown spots on ventral side of body forming several lines. Caudal fin light yellow with reddish brown marginal regions. External edges of dorsal and anal fins with yellow line. Three dark brown grooves on cheek.

The proportional measurements and counts of fin rays and scales of the specimen collected are shown in Table1 with comparisons with those provided by Randall et al. (1978), Matsuura (1980) and Nair et al. (2013). X. lineopunctatus is partly similar to $X$. ringens and $X$. greenei in having three pigmented grooves on cheek and color of body and fins. $X$. ringens can be distinguished from $X$. lineopunctatus in having many dark brown spots making longitudinal lines (vs many longitudinal dark lines on lateral part of body) and 39-44 body scales (vs 46 body scales). It also differs from $X$. greenei in having the dark brown line on the base of the soft dorsal and anal fins and occurrence of 46 body scales (vs 33-35 body scales).

$X$. lineopunctatus occurs widely in the tropical Indo-West Pacific in coral and rocky reefs from the coast line to a depth of 100 m (Randall et al., 1978). However, we recorded the species

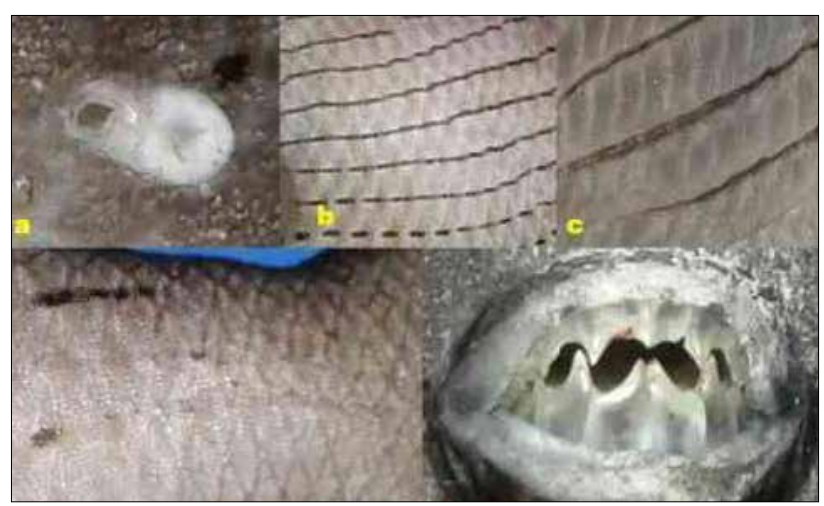

Fig. 2. a. Nasal aperture, b. Body scales, c. Scales on cheeks d. Scales on caudal peduncle, e. Teeth pattern

from the area without coral reefs along Visakhapatnam coast. The present specimen was caught in commercial trawls as bycatch. $X$. lineopunctatus mainly feeds on bottom invertebrates including mollusks and crabs followed by zooplankton (Froese and Pauly, 2016). On dissecting the species, it was found that the stomach contents constituted mostly of broken crab shells and zooplankton mainly copepods. In recent years, along 
the east coast of India, due to incidence of severe cyclonic storms, active upwelling of coastal waters is reported to occur, enhancing the abundance of planktonic crustacean copepods, one of the preferred prey items of $X$. lineopunctatus (Baliarsingh et al., 2014).

Table 1. Comparisons of proportional measurements and counts of fin rays and scales of Xanthichthys

\begin{tabular}{|c|c|c|c|c|}
\hline $\begin{array}{l}\text { Morphometric } \\
\text { measurements (mm) }\end{array}$ & $\begin{array}{l}\text { Matsuura, } \\
1980\end{array}$ & $\begin{array}{l}\text { Randall, } \\
\text { et. al., } 1978\end{array}$ & $\begin{array}{l}\text { Nair, } \\
\text { et. al., } 2013\end{array}$ & $\begin{array}{l}\text { Present } \\
\text { study }\end{array}$ \\
\hline \multicolumn{5}{|c|}{ In standard length } \\
\hline Greatest body depth & $1.83-2.11$ & * & * & 1.94 \\
\hline Body depth & $2.59-2.67$ & $2.59-2.80$ & $2.66-2.7$ & * \\
\hline Width of body & $5.03-3.13$ & $5.03-6.25$ & * & 5.19 \\
\hline Head length & $3.03-3.13$ & $2.97-3.26$ & $2.97-3.1$ & 2.87 \\
\hline Snout length & $4.79-4.80$ & $4.51-4.80$ & $5.03-5.1$ & 4.92 \\
\hline $\begin{array}{l}\text { Snout to origin of first } \\
\text { dorsal fin }\end{array}$ & $2.94-3.05$ & $2.94-3.09$ & $3.4-3.5$ & 5.50 \\
\hline \multicolumn{5}{|l|}{ Snout to origin of second } \\
\hline dorsal fin & $1.66-1.69$ & $1.66-1.71$ & $2.6-2.7$ & 2.49 \\
\hline Snout to origin of anal fin & $1.48-1.50$ & $1.42-1.50$ & $1.6-1.67$ & 2.30 \\
\hline Base of second dorsal fin & $2.87-2.95$ & $2.68-2.95$ & $3-3.22$ & 2.79 \\
\hline Base of anal fin & $3.2-3.27$ & $3.05-3.4$ & $3.6-3.7$ & 3.06 \\
\hline \multicolumn{5}{|c|}{ In head length } \\
\hline Eye diameter & $5.92-6.16$ & $4.30-6.16$ & $5.70-6.4$ & 5.41 \\
\hline Inter orbital width & $2.63-2.65$ & $2.63-2.93$ & $3.6-3.7$ & 2.95 \\
\hline Length of gill opening & $3.20-3.43$ & $3.08-3.84$ & $3.5-3.6$ & 3.095 \\
\hline Length of caudal peduncle & $2.56-2.91$ & * & $2.6-2.8$ & 2.60 \\
\hline Depth of caudal peduncle & $3.98-4.23$ & $3.78-4.84$ & $2.34-2.5$ & 3.25 \\
\hline Length of first dorsal spine & $2.07-2.15$ & $2.07-2.48$ & $2.34-2.49$ & 2.16 \\
\hline $\begin{array}{l}\text { Length of longest (sixth) } \\
\text { second dorsal ray }\end{array}$ & $1.74-1.95$ & $1.39-1.95$ & $1.6-1.9$ & 1.96 \\
\hline $\begin{array}{l}\text { Length of longest (third) } \\
\text { anal ray }\end{array}$ & $1.89-2.04$ & $1.5-2.04$ & $1.67-1.92$ & 2.24 \\
\hline Inter dorsal space & $1.31-1.4$ & $1.19-1.4$ & 3.2 & 2.95 \\
\hline Length of pectoral fin & $3.29-3.54$ & $2.5-3.06$ & $3.1-3.2$ & 2.60 \\
\hline Length of caudal fin & $1.38-1.8$ & $1.38-1.88$ & $1.78-1.8$ & 1.44 \\
\hline \multicolumn{5}{|c|}{ Meristic measurements } \\
\hline Dorsal fin & III, 28 & $27-29$ & 29 & III, 28 \\
\hline Anal fin rays & $25-26$ & $25-26$ & $25-26$ & 25 \\
\hline Pectoral fin rays & $13-14$ & $13-14$ & $12-13$ & 13 \\
\hline Pelvic fin rays & * & * & * & * \\
\hline Caudal fin rays & * & * & $10+2$ & 12 \\
\hline Body scale rows & $44-46$ & $44-50$ & 47 & 46 \\
\hline Head scale rows & $17-19$ & $17-21$ & 17 & 18 \\
\hline Weight (gm) & * & * & * & 212 \\
\hline
\end{tabular}

\section{Acknowledgements}

The authors are grateful to the Director, ICAR-Central Marine Fisheries Research Institute, Kochi and Head, Marine Biodiversity Division, ICAR-CMFRI for their constant encouragement and support.

\section{References}

Baliarsingh, S. K., C. Parida, A. A. Lotliker, S. Srichandan, K. C. Sahu, and T. S. Kumar 2014. Biological implications of cyclone Hudhud in the coastal waters of northwestern Bay of Bengal. Curr. Sci., 109 (7): 1243-1245.

Eschmeyer, W. N. and J. D. Fong. 2016. Catalog of fishes, version (4/2016) available at: http://www.research.calacademy.org (accessed 23 August2016).

Froese, R. and D. Pauly. 2016. Fish Base, version (04/2016). Available at: http://www. fishbase.org (accessed 23 August 2016).

Matsuura, K. 1980. A revision of the Japanese balistoid fishes. I. Family Balistidae. Bull. Nat. Sci. Mus. Tokyo, and Series A (Zoology), 6: 27-69.

Nair, R. J., K. Dinesh, P. M. Geetha, and K. Somy. 2013. Range extension of the striped triggerfish Xanthichthys lineopunctatus (Tetraodontiformes: Balistidae) from India. Mar. Biod. Rec., 6: 1-3.

Randall, J. E., K. Matsuura, and A. Zama. 1978. A revision of the triggerfish genus Xanthichthys, with description of a new species. Bull. Mar. Sci., 28: 688-706. 